\section{リネンと衛生材料 *}

一特に不織布と従来のもの

$\begin{array}{llll}\text { 小 } & \text { 西 } & \text { 康 } & \text { 夫** } \\ \text { 芦 } & \text { 田 } & & \text { 真 } \\ \text { 荒 } & \text { 川 } & \text { 洋 } & \text { 造 }\end{array}$

一技街解説

\section{1.はじめに}

医療分野に不織布が紹介されてよりすでに10数年にな り，いろいろなディスポーザブル商品の展開が行われ ていたが，昭和48年の石油パニックにより節約ムードと なり，伸びつつあった不織布の各種商品も後退の止むな きに到った。しかし昨今は再びわずかながらも，伸長を みせ始めて来た。

一方, 衛生思想の変化や医療の向上, 新素材, 複合素 材と原料部門の進歩とともに，加工技術，商品展開技術 の向上により医療分野における不織布製品に対する安定 した需要が確保できると信じる.

そてで, 従来より使用されている不織布以外のもの と，不織布とを各項目について比較検討し，それらの問
題点のいくつかについて述べる.

\section{2. 衛生材料の薬事法上の分類}

ガーゼ，包帯，脱脂綿ぐらいしかなかった衛生材料 も，いろいろな素材を原料としてかなりの品種の商品が できて来た。

これらの大部分のものは薬事法の規制下にあるが，薬 事法上の分類を表 1 亿示す.

薬事法は，医薬品，医薬部外品，医療用具等に明確に 区別している.

更に，分類上まぎらわしいものについては，「ガーゼ 代用紙綿類の取扱いについて」の厚生省の課長通達 ${ }^{1)}$ が 出されている.

またその規格は表 1 亿示すように日本薬局方，生理処 理用品基準等で定められている.

しかし薬事法の規制下にありながら規格が公示されて いない品目については，厚生省に製造承認申請を行う際 に自社にて設定した規格と，その規格を設定した根拠と なる測定值等の技術資料ならびに試験方法等を添えて申 請すれば良い。

ただし上記申請以前に医薬品，医薬部外品，医療用具 等の製造業または輸入販売業の業態の許可取得が，前提 条件であり，手続等の明細については，薬事法に明確に 述べられている。

\section{3．衛生材料の生産量}

年間700億円ぐらいの市場であるが，全品目の生産統

表 1 衛生材料の薬事法上の分類

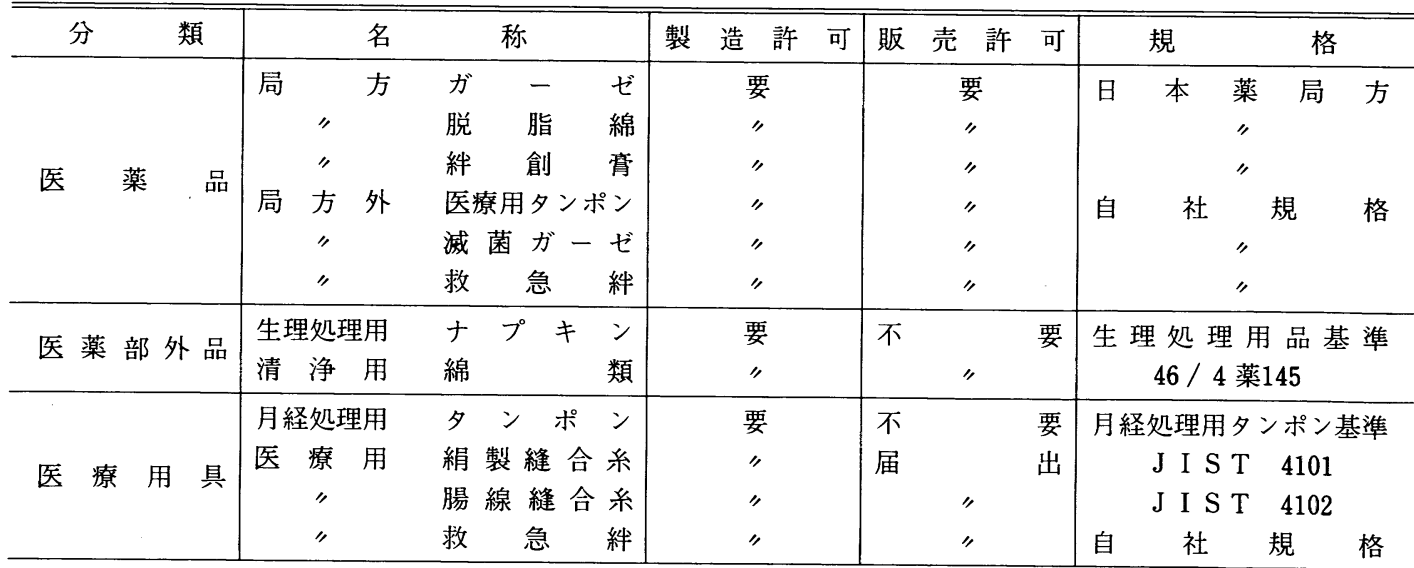

注）規制外のもの：包帯, 伸縮包帯, ギブス包帯, 綿包帯, ネット包帯, 包帯止, 三角布, リント布, 腹帯, マスク お産用パッド，紙おむつ

\footnotetext{
* Outline of Surgical Dressings and Linen Materials in Japan. - Especially in Comparing with Non-Woven Products.
}

* Y. Konishi, M. Ashida, Y. Arakawa, 川本繃帯材料 開発部 
表 2 主要衛生材料の品目別・生産量

(単位：トン)

\begin{tabular}{c|c|r|r|r|r}
\hline \hline & 昭和47年 & 昭和48年 & 昭和50年 & 昭和51年 & \multicolumn{2}{|c}{ 昭和52年 } \\
\hline 局 方 ガーゼ & 2300 & 3000 & 1700 & 2100 & 2300 \\
" 脱 脂 綿 & 11000 & 12000 & 8000 & 8000 & 7000 \\
(生)ナプキン & 46000 & 51000 & 46000 & 49000 & 52000 \\
紙 お むつつ & & & 7000 & 7300 & 7500 \\
\hline
\end{tabular}

（日本衛生材料工業連合会より）

表 3 各種不織布の純度比較

\begin{tabular}{l|r|c|r|r|r|r|c}
\hline \hline & $\mathrm{A}$ & $\mathrm{B}$ & $\mathrm{C}$ & $\mathrm{D}$ & $\mathrm{E}$ & $\mathrm{F}$ & $\mathrm{G}$ \\
水溶性物質 $(\mathrm{mg})$ & 10.3 & 7.2 & 12.2 & 992.3 & 37.1 & 56.5 & 80.1 \\
灰 分 $(\mathrm{mg})$ & 4.0 & 6.7 & 5.1 & 8.7 & 42.4 & 43.3 & 76.0 \\
酸またはアルカリ & 中性 & 中性 & 中性 & 中性 & 中性 & 中性 & 中性 \\
沈 降 速 度 $(\mathrm{sec})$ & 1.5 & 1.9 & 1.6 & 6.5 & 3.2 & 3.5 & 11.7 \\
\hline
\end{tabular}

デキストリンまたはデンプン：色素：蛍光增白剤……全検体適

注）日本薬局方ガーゼの試験法の純度試験による
$\mathrm{A} ：$ 局方ガーゼ B：局方脱脂綿
$\mathrm{C} ：$ キュプラ スパンボンド
$\mathrm{D} ：$ レーヨン・パルプ湿式
$\mathrm{E} ：$ レヨン ニードル パンチ
F：レーヨン スティッチ ボンド
$\mathrm{G}:$ レーヨン 乾 式

計は完備されていない.

厚生省か薬事動態調査を定期的に行っているが，日本 衛生材料工業連合会が上記調査を根拠に発表した生産統

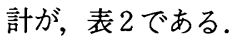

(a) ガーゼ

昭和47年に急伸し更に昭和48年の石油パニック時に， 仮需要により急伸したが，生産過多により過剩流通在庫 の解消にほほ 3 年を要し，昨今は微増を示している．ガ 一ゼ代用としての不織布は，医療分野へは数％，産業資 材用には10～20\%進出したと思われるが，根拠となる公 式統計は見当らない.

(b) 脱脂綿

最大の用途であった女性の生理処理用の用途は，生理 用ナプキンにその座を譲り，脱脂綿の大手製造業者の数 社は倒産し，かなりの業者が休，廃業したものの依然過 剰設備を有している.

また，余った脱脂綿の設備を利用して女性の化粧用に 綿製のパフの市場70億円を形成したものの，市場におい てはティッシュペーパと競合し過当競争を展開してい る.

一方，毎年160万余の赤ちゃんが生まれるが産褯時に 使用される脱脂綿も，かなりの量であった。しかし昨今 は複合素材によるお産用パッドにほとんどとってかわら れた。

脱脂綿代用の不織布としては，前述の化粧パフ，お産 用パットの表面材に使用されており，年間数百トン程度 のものと思われる.

(c) 生理用ナプキン

ここ10年間脱脂綿にとってかわってめざましい成長を 示したものの, 成長は停滞し年数\%ぐらいの成長しか見
込めず，昨今はタンポンに追われる立場になった。 この用途においても不織布はカバー材料に使用され，年 間8 000 トンに達しその廉価さ，肌触り，スポット吸収， 等の特性を上手に生かしている.

(d) 紙おむつ

成人用は順調に伸展しているが，乳児用については伸 びなやみでありその原因は，商品自体よりむしろ製品価 格にあると考えられている。

この用途における不織布もカバ一材料として使われ， 年間数百トン程度であろう。

(e) $\mathrm{T}$ 字帯

防水シーツ，シーツ，三角布などに不織布は使われて いるが，いずれも微々たる数量と思われる.

ただし T字帯については，廉価で，ディスポーザブル にできる利点により, 綿布製より不織布製の方が多くなっ て来た。

\section{4. 不織布の純度比較}

昭和 46 年頃より不織布が医療用途に吸収材料等として 使用できないかと検討されて来だ．

その頃に局方ガーゼ，脱脂綿と各種不織布の純度につ いて，比較検討した值が，表 3 である。

バインダを使用した不織布は，当然水溶性物質と兏分 が多い

\section{5. 医療用の吸収材料に要求される特性}

医療用途に不織布の導入を考える時に，まず考えられ るのが吸収材としての用途であろう。

医療用の吸収材に要求される特性は下記の通りであ る. 
表 4 㓕菌条件

\begin{tabular}{|c|c|c|c|c|c|}
\hline & & & 高圧蒸気滅菌 & E.Oガス滅菌 & 放 射 線 滅 菌 \\
\hline \multirow{2}{*}{\multicolumn{2}{|c|}{$\begin{array}{l}\text { 日本薬局方 } \\
\text { 滅 菌 法 }\end{array}$}} & 条件 & $\begin{array}{ll}115^{\circ} \mathrm{C} & 30 \mathrm{~min} \\
121^{\circ} \mathrm{C} & 20 \mathrm{~min} \\
126^{\circ} \mathrm{C} & 15 \mathrm{~min} \\
\end{array}$ & $\begin{array}{l}\text { 温度・湿度 } \\
\text { 濃度・時間 }\end{array}$ & ${ }^{60} \mathrm{Co}$ または ${ }^{137} \mathrm{Cs}$ \\
\hline & & 注意事項 & 飽 和 水 蒸 気 & 残留ガス・生成物 & 線量を調節 \\
\hline \multirow{2}{*}{ 英 } & \multirow{2}{*}{ 国 } & 条 件 & $\begin{array}{rr}115^{\circ} \sim 116^{\circ} \mathrm{C} & 30 \mathrm{~min} \\
134^{\circ} \sim 138^{\circ} \mathrm{C} & 3 \mathrm{~min} \\
\end{array}$ & $\begin{array}{l}\text { 温度・湿度 } \\
\text { 圧力・調整 } \\
\end{array}$ & $2.5 \mathrm{Mrad}$ 以上 \\
\hline & & 指 標 菌 & & $\begin{array}{l}\text { B. subtilis var } \\
\text { globigii } \\
\text { NCTC } 10073,10^{6}\end{array}$ & \\
\hline \multirow[t]{2}{*}{ 米 } & \multirow[t]{2}{*}{ 国 } & 条件 & $\begin{array}{l}\text { 最 低 } \\
121^{\circ} \mathrm{C} \quad 15 \mathrm{~min}\end{array}$ & $\begin{array}{l}\text { 1. } 38 \sim 60^{\circ} \mathrm{C} \\
\text { 2. } \mathrm{RH} 25 \sim 50 \% \\
\text { 3. } 450 \mathrm{mg} / \ell \sim 760 \mathrm{mg} / \ell\end{array}$ & ${ }^{60} \mathrm{Co}$ 一または ${ }^{137} \mathrm{Cs}$ \\
\hline & & 指 標 菌 & B. stearothermophilus & B. subtilis & B. pumilus \\
\hline \multirow[t]{2}{*}{$\begin{array}{l}\text { 日 } \\
\text { 現 }\end{array}$} & \multirow[t]{2}{*}{$\begin{array}{l}\text { 本 } \\
\text { 行 }\end{array}$} & 条件 & $\begin{array}{ll}121 \sim 123^{\circ} \mathrm{C} & 20 \sim 30 \mathrm{~min} \\
130 \sim 134^{\circ} \mathrm{C} & 15 \sim 20 \mathrm{~min} \\
140 \sim 143^{\circ} \mathrm{C} & 20 \sim 30 \mathrm{~min} \\
\end{array}$ & $\begin{array}{l}38 \sim 60^{\circ} \mathrm{C} \\
\text { RH } 50 \% \text { 以下 } \\
2 \sim 3 \mathrm{hr} \\
\end{array}$ & $2.5 \sim 4.5 \mathrm{Mrad}$ \\
\hline & & 指 標 菌 & B. stearothermophilus & B. subtilis & B. subtilis \\
\hline $\begin{array}{l}\text { 留 } \\
\text { 問 }\end{array}$ & $\begin{array}{l}\text { す } \\
\text { 題 }\end{array}$ & $\begin{array}{c}\text { き } \\
\text { 点 }\end{array}$ & $\begin{array}{llll}\text { 1. 包 } & \text { 装 } & \text { 材 } & \text { 料 } \\
\text { 2. 劣 } & & & \text { 化 } \\
\text { 3. 排 } & & & \text { 気 }\end{array}$ & $\begin{array}{l}\text { 1. 包装 材 } \text { 料 } \\
\text { 2. 残 留 ガ } \\
\text { 3. 作業員の安全 }\end{array}$ & 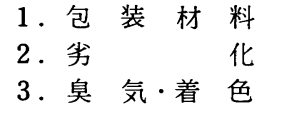 \\
\hline
\end{tabular}

1，血や膿を吸収できること

2. 人体に反応を生じないてと

3. 柔らかくてしかも適当な強度があるてと

4. 脱落物質がないとと

5. 廃棄する際に問題を発生しないてと

6. 㓕菌できること

\section{6. 滅菌の条件}

医療用途江不織布の導入を検討する際，その滅菌工程 がメーカまたは病院で行われようとも，减菌可能である ことが必要であり，乙れは避けて通れない条件の一つで ある。

各国の薬局方で定められている㙎菌に関する条件，ま た日本の病院で現実に行われている㓕菌の条件，その際 に留意すべき問題点を表 4 亿示す.

(a) 高圧蒸気㓕菌法

病院において一番多く採用されている方法であるが， 近年, 高温度で短時間に㓕菌処理を終える機器（オート クレーブ）に変る傾向にあり，そのため被减菌物の劣化 を招きやすい場合もある.

滅菌済品のメーカでは, 商品価值を損いやすいのでて の方法はあまり利用されていない。

(b) 酸化エチレンガス滅菌法（E.Oガス滅菌）

熱に弱いゴム，プラスチックなどの㓕菌に適してお り, 昨今では大多数の病院で採用されている. 滅菌済品 のディスポーザブル品メーカが，もっとも多く利用して
いる滅菌法である.

不織布を㓕菌するには，乙の方法がもっとも適した方 法と考えられるが，E.Oガスの吸着による残留毒性およ び作業員の安全には，細心の注意が必要である。

(c) 放射線㓕菌法

日本では一部の㓕菌済ディスポーザブル品メ一カか採 用しているが，現在では㓕菌コストは他の方法にくらべ て安くはない。

\section{7. 隇菌の確認}

减菌できているかどうかは, 通常, 堿菌工程終了後被 减菌物を，日本薬局方に定めた無菌試験法に準じ試験し 確認される.

\section{8. 隇菌の工程管理}

\section{1 隇菌前生菌数}

㓕菌工程確立のためには，减菌を行う前に被㓕菌物が 微生物によりどの程度污染されているか, その菌数を調 べ，污染の程度により滅菌条件を設定すべきである.

参考として, 衛生材料の各工程における生菌数を表 5 ${ }^{4)}$ に, 市販している未㓕菌の衛生材料の付着菌数を表 6 に示す.

\section{2 指標菌, ケミカル インディケータ}

㓕菌の程度を表す物差しとして表 4 亿示した指標菌を 使用する.

指標菌同志の抵抗性を比較するには，D值（菌数を1/10 
表 6 未滅菌衛生材料市販品の付着生菌数 ${ }^{4)}$

(個 / $\mathbf{g}$ )

\begin{tabular}{c|c|c|c|c|c|c|c|c|c|c}
\hline \hline & 0 & $1 \sim 5$ & $6 \sim 10$ & $11 \sim 20$ & $21 \sim 50$ & $51 \sim 100$ & $101 \sim 200$ & $201 \sim 500$ & $501 \sim 1000$ & $\overline{\mathrm{M}}$ \\
\hline ガ 一 ゼ & 0 & 9 & 4 & 11 & 24 & 36 & 5 & 0 & 0 & 51.3 \\
\hline 脱 脂 綿 & 0 & 3 & 5 & 11 & 23 & 24 & 16 & 2 & 1 & 85.0 \\
\hline
\end{tabular}

表 5 衛生材料の各工程における生菌数 ${ }^{4)}$ (a) 局方ガーゼ

\begin{tabular}{cc|c|c|lc}
\hline \hline 原 & 料 & 工程 I & 工程 II & 製 & 品 \\
\hline $10^{5} \sim 10^{6}$ & $10^{5} \sim 10^{7}$ & $10^{1} \sim 10^{3}$ & $10^{0} \sim 10^{2}$ \\
\hline
\end{tabular}

(b) 局方脱脂綿

\begin{tabular}{c|c|c|cc}
\hline \hline 原 & 料 & 工 程 I & 工 程 II & 製 \\
\hline $10^{6} \sim 10^{7}$ & $10^{5} \sim 10^{6}$ & $10^{1} \sim 10^{3}$ & $10^{\circ} \sim 10^{2}$ \\
\hline
\end{tabular}

にするに要する時間）が使われている.

確立された㓕菌工程では, 化学反応により変色する物 質を使ったケ之カル インディケータを滅菌の成否の目 安に使用する場合がある. しかし，ケミカルインディ ケータは，通常湿度に弱くロットでとに色調にかなりの 差があり, 経時変化をする物が多いので, あくまで目安 にしかすぎず，㓕菌工程確立には，微生物を使用すべき である

\section{3 滅菌済品に使用される包装材料}

被滅菌物や滅菌方法に適合させて各種の包装材料が使 われる。乙れらは滅菌の成果, 滅菌時間の短縮, 無菌状 態の保持効果, 使用時の開けやすさ, 使用後の廃棄, コス ト，等々の点より検討されるべきである．また，紙質， プラスチックのフィルム, プラスチックの成型品, 不織 布, などの包装材料は, それぞれの長所と, 短所をも ว.

しかし筆者らは酸化エチレン (E.O) ガス滅菌用に は，紙質がもっとも優れていると考える.

その理由を下記に示す。

1. 减菌は短時間で,むらなく行われる

2. 㓕菌後の残留 E.O ガスは, 他の材質の包装材料 より, 最も早く検知限界に達する

3 . 使用後の廃棄についても, 問題が少ない

包装材料の検討, 减菌後の被滅菌物の無菌状態の長期間 保持性の検討に，ユーザ側の環境条件を上記の検討に加 味すべきであり, 病院内の空中細菌数の例を表 $7^{6)}$ に示 す.

\section{9. 医療用不織布試験法}

3 年前より国立衛生試験所療品部の指導のもとに I N DA（国際不織布協会）日本支部, 不織布メ一力有志, 衛生材料メ一カ有志と日本不織布工業会および日本 衛生材料工業連合会により医療用不織布研究委員会が設
表 7 病院内の空中細菌数 ${ }^{6)}$

\begin{tabular}{|c|c|c|c|}
\hline 場 & 所 & 範 囲 & 平均値 \\
\hline 病 棟 & 廊 下 & $6 \sim 80$ & 24 \\
\hline " & 病 室 & $10 \sim 51$ & 25 \\
\hline 外 科 & 廊 下 & $4 \sim 130$ & 26 \\
\hline " & 手術室 & $1 \sim 80$ & 10 \\
\hline " & 洗浄室 & $2 \sim 61$ & 16 \\
\hline 分婏室 & & $2 \sim 7$ & - \\
\hline \multirow[t]{2}{*}{ 洗濯室 } & 選 別 & $25 \sim 78$ & 50 \\
\hline & 洗 濯 & $12 \sim 74$ & 28 \\
\hline
\end{tabular}

立され，種々の検討が行われて来た。

医療用不織布研究委員会で討議された内容の一部を報 告する。

\section{、医療用不織布試験法（案）}

\section{I. 定 義}

本品は, 繊維を化学的または機械的に処理して, 結合 させ布状としたもので，减菌され創面に使用できるもの をいう。

II. 化学的試験

1. 溶出物試験

(1) $\mathrm{pH}$

(2) あわ立ち

（3）過マンガン酸カリウム環元性物質

（4）蒸発残留物

(5) 色 素

2. ホルムアルデヒド

3. 重金属

4. 灰分

III. 物理的試験
1. 引張試験
5 . 脱落繊維
2. 白度
6. 沈降速度
3. 臭気
7 . 吸水量
4. 螢光増白剤

N . 無菌試験

V. 生物学的試験
1. 発熱性物質試験
2. 急性毒性試験
3. 皮膚反応試験
4. 眼刺戟試験

V. 表 示

1. 厚さ

2. 目付け 


\section{0. 隇菌による不織布などの物性変化}

各種不織布の放射線煘菌による化学的物性変化の一部 を図 1 亿示す ${ }^{5}$.

溶出物のPHは, 放射線量の増加に伴い減少し, 過 マ ンガン酸カリウムの消費量と蒸発残留物は，いずれも放 射線量の増加に伴い増加している.

遊離のホルムアルデヒドも放射線量の増加とともに増
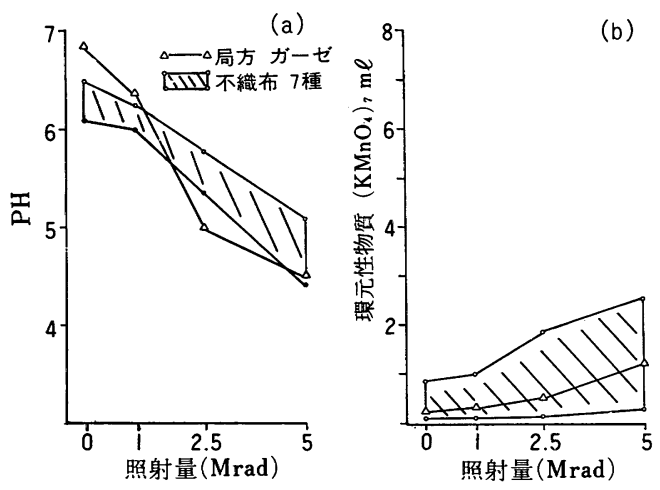
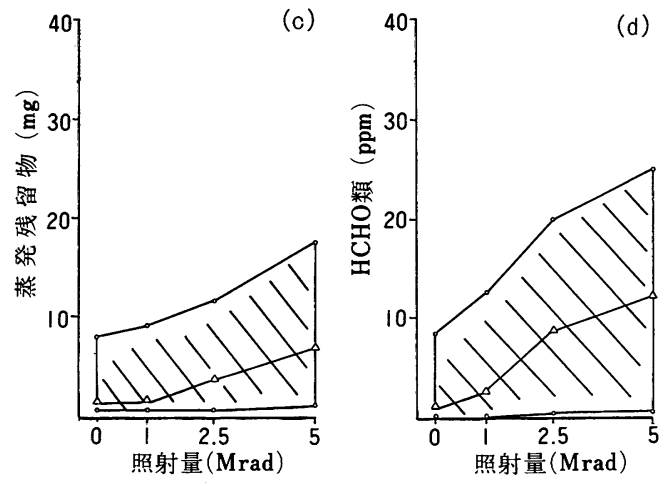

加する.

図 1 放射線减菌による变化 ${ }^{5)}$

また蒸発残留物とホルムアルデヒドは，バインダを使 用した不織布の方が，ノ一 バインダの不織布より高い 数值を示す.

不織布 2 種と局方脱脂綿の E.O ガス滅菌後の E.O ガス残留量を図 2 に示す.

異なった 3 種の包装袋に入れて，日本薬局方ガーゼを E.O ガス减菌したのちの E.O ガス残留量を図 3 に示 表 8 高圧蒸気隇菌による変化 ${ }^{8)}$ 病院で 1 回再生後の性状

\begin{tabular}{|c|c|c|c|c|c|c|c|c|}
\hline & & $\begin{array}{c}\text { 水溶性物質 } \\
(\%)\end{array}$ & $\begin{array}{l}\text { けい光 } \\
\text { 増白剤 }\end{array}$ & $\begin{array}{c}\text { 沈降速度 } \\
(\mathrm{sec})\end{array}$ & $\begin{array}{c}\text { 疢 分 } \\
(\%)\end{array}$ & $\begin{array}{c}\text { タンパク質 } \\
(\%)\end{array}$ & $\begin{array}{c}\text { 脂 肪 } \\
(\%)\end{array}$ & $\begin{array}{c}\text { 白色度 } \\
(\%)\end{array}$ \\
\hline & & $\overline{\mathrm{M}}$ & $\overline{\mathrm{M}}$ & $\overline{\mathrm{M}}$ & $\overline{\mathrm{M}}$ & $\overline{\mathrm{M}}$ & $\overline{\mathrm{M}}$ & $\overline{\mathrm{M}}$ \\
\hline 局 & 方 & 0.25 以下 & $\begin{array}{l}\text { 全面に染着 } \\
\text { されない }\end{array}$ & $8 \mathrm{sec}$ 以内 & 0.25 以下 & & & \\
\hline 対 & 照 & $0.03 \sim 0.07$ & " & $1.1 \sim 1.5$ & $0.04 \sim 0.08$ & $0.01 \sim 0.04$ & $0.15 \sim 0.18$ & $78.4 \sim 79.0$ \\
\hline & & 0.04 & 全面染着 & 1.35 & 0.08 & 0.15 & 0.19 & 79.1 \\
\hline & & 0.08 & $"$ & 1.28 & 0.06 & 0.31 & 0.20 & 77.4 \\
\hline & & 0.09 & " & 1.42 & 0.03 & 0.12 & 0.30 & 78.5 \\
\hline & & 0.11 & $"$ & 1.62 & 0.12 & 0.01 & 0.01 & 79.3 \\
\hline
\end{tabular}

(測定方法)

○水溶性物質, けい光増白剤, 沈降速度 : 第 8 改正日本薬局方ガーゼの試験法

Oタンパク質：衛生試験法注解・タンパク性窒素定量法

○脂肪：衛生試験法注解・脂質試験（エーテル抽出法）

病院で 1 回再生後の品質

\begin{tabular}{|c|c|c|c|c|c|c|c|c|c|}
\hline & & \multicolumn{2}{|c|}{ 収 縮 率 (\%) } & \multicolumn{2}{|c|}{ 引張強さ（kg） } & \multicolumn{2}{|c|}{ 引張伸度 (\%) } & \multicolumn{2}{|c|}{ 引裂強さ $(\mathrm{kg})$} \\
\hline & & 縦 & 横 & 縦 & 横 & 縦 & 横 & 縦 & 横 \\
\hline & & $\overline{\mathrm{M}}$ & $\overline{\mathrm{M}}$ & $\overline{\mathrm{M}}$ & $\overline{\mathrm{M}}$ & $\overline{\mathrm{M}}$ & $\overline{\mathrm{M}}$ & $\bar{M}$ & $\overline{\mathrm{M}}$ \\
\hline 対 & 照 & $2.5 \sim 3.0$ & $2.0 \sim 2.5$ & $5.2 \sim 6.8$ & $5.2 \sim 6.4$ & $7.3 \sim 11.3$ & $8.7 \sim 11.7$ & $1.0 \sim 1.2$ & $0.9 \sim 1.2$ \\
\hline & & $(-)$ & 2.5 & 5.2 & 5.5 & 8.7 & 9.7 & 1.0 & 1.0 \\
\hline & & 0.5 & 1.5 & 5.2 & 5.6 & 10.7 & 12.3 & 1.1 & 1.1 \\
\hline & & 1.0 & 1.5 & 5.6 & 5.1 & 8.7 & 11.3 & 0.9 & 0.8 \\
\hline & & 0.8 & 1.2 & 5.2 & 5.5 & 9.2 & 9.6 & 1.2 & 1.1 \\
\hline
\end{tabular}

(測定方法)

○収縮率：J I S L - 1042「織物の収縮率試験方法」F 2 法

○引張強さ：J I S L-1068「織物の引張試験方法」

○引張伸度：同上

O引裂強さ：J I S L - 1004「綿織物試験方法」C法 


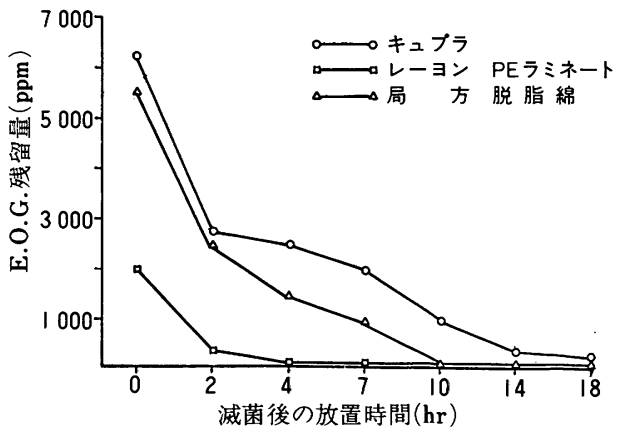

図 2 E. O. G. の残留”

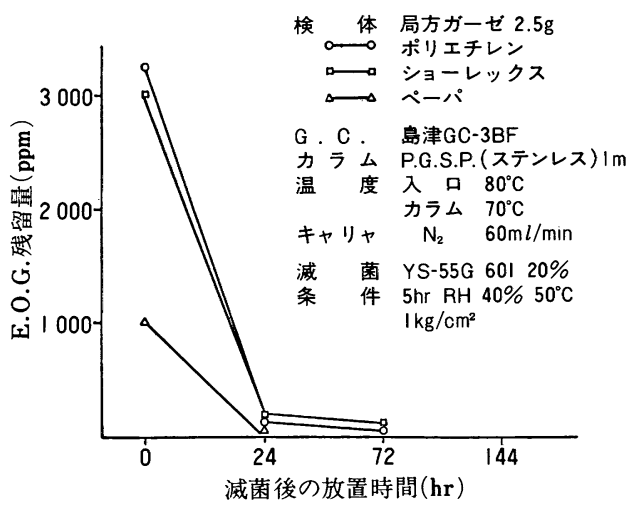

図 3 E．O．G．の残留

す.

日本薬局方ガーゼを, 高圧蒸気滅菌した後使用し再生 したものの物理的, 化学的変化を表 $8^{8)}$ に示す.

\section{1. 清浄綿について}

清浄綿とは，いわゆるウェットワイパで，厚生省課 長通達で ${ }^{2)}$ 医薬品, 医薬部外品, 規制外の雑貨扱のも の，と明確に区分されている.

素材としては, 脱脂綿, 不織布, 紙が使われ, いずれ も殺菌剤を含浸し，湿潤状態のまま包装されたものであ る.

殺菌剤の吸着, ピン ホールによる内容物の乾燥および かびの発生等が問題点である.
清浄綿の経時的水分减少率を表 9 亿示す.

脱脂綿に対する殺菌剤の吸着を表10に示す.

表10 脱脂綿に対する殺菌剤の吸着 ${ }^{10}$

\begin{tabular}{|c|c|}
\hline 製 品 名 & 飽和吸着量 $(\mathrm{mg} / \mathrm{g})$ \\
\hline 硬 質 絹 糸 & 37 \\
\hline 軟 質 綟 系 & 20 \\
\hline 脱 脂 & 6 \\
\hline ろ & 6 \\
\hline ガ $\quad-$ & 2 \\
\hline
\end{tabular}

$0.02 \%$ クロール ヘキシジン $25^{\circ} \mathrm{C}$

\section{2. リネンについて}

リネンとは亜麻の一種ではあるが，一般的には布類， 病院においては，ベットカバー，手術衣，覆布，白衣な どをリネン材料と呼んでいる.

手術衣, 覆布, マスクなどに, 要求される物性は，下 記のとおりである.

1. 細菌を透さないてと

2. 撥水性があること

3. 吸湿性があること

4. 通気性があること

5 。発塵性がないとと

6.ドレープ性があること

7 。適当な強度があること

8. 滅菌できるてと

9. 静電気を起てさないとと

国内の病院では，リネン材料のほとんどは，綿の織物 を使用している.

合繊の織物は，蒸気滅菌に耐えにくいとと，静電気を 防止しにくいてとなどによりほとんど使われていない.

前述の条件を全部満足している手術衣などは，いまだ 開発されていないので，ある面では不織布が進出できる 市場か残されている.

しかし不織布はその耐久性において，従来の綿に劣る 割りには，コストが高い. 縫製加工等のコスト高要因が 除かれれば，不織布は細菌透過阻止能力，片面撥水，片

表 9 清浄綿の経時水分減少率 $(\%)^{9)}$

\begin{tabular}{|c|c|c|c|c|c|}
\hline 放置条件 & 包 & 1 週間後 & 4 週間後 & 8 週間後 & 13週間後 \\
\hline \multirow{2}{*}{ 常 温 常 湿 } & アルミ 䈃 & $0 \sim 0.2 \%$ & $0 \sim 0.2 \%$ & $0 \sim 0.2 \%$ & $0 \sim 0.2 \%$ \\
\hline & ポリエチレン & $0.1 \sim 0.6 \%$ & $0.3 \sim 1.3 \%$ & $0.8 \sim 3.1 \%$ & $1.7 \sim 5.9 \%$ \\
\hline \multirow{2}{*}{$20^{\circ} \mathrm{C}$ RH $65 \%$} & アルミ䈃 & $0.1 \sim 0.3 \%$ & $0.1 \sim 0.5 \%$ & $0.1 \sim 0.5 \%$ & $0.1 \sim 0.5 \%$ \\
\hline & ポリエチレン & $0.4 \sim 1.3 \%$ & $1.3 \sim 4 \%$ & $2.7 \sim 7.9 \%$ & $5.1 \sim 13.3 \%$ \\
\hline \multirow{2}{*}{$40^{\circ} \mathrm{C} \quad \mathrm{RH} 80 \%$} & アルミ 箔 & $0.1 \sim 0.5 \%$ & $0.2 \sim 0.6 \%$ & $0.2 \sim 0.6 \%$ & $0.2 \sim 0.7 \%$ \\
\hline & ポリエチレン & $0.4 \sim 1.7 \%$ & $2 \sim 5.7 \%$ & $3.8 \sim 10.6 \%$ & $6.3 \sim 17.9 \%$ \\
\hline \multirow{2}{*}{$40^{\circ} \mathrm{C}$ RH $0 \%$} & ア ルミ 箔 & $0 \sim 0.4 \%$ & $0.2 \sim 0.6 \%$ & $0.2 \sim 0.7 \%$ & $0.2 \sim 0.9 \%$ \\
\hline & ポリエチレン & $0.3 \sim 1.1 \%$ & $10.4 \sim 25.3 \%$ & $2.2 \sim 5.0 \%$ & $37.4 \sim 7.9 \%$ \\
\hline
\end{tabular}


表11 手術着の細菌捕集効率 $(\%)^{11)}$

\begin{tabular}{|c|c|c|c|c|c|c|}
\hline \multirow{2}{*}{ 手 術着 の 種 類 } & \multicolumn{5}{|c|}{ テスト 回 数 } & \multirow{2}{*}{ 平均 } \\
\hline & 1 & 2 & 3 & 4 & 5 & \\
\hline $\begin{array}{l}\text { 綿 } \mathrm{A} \\
\text { (かつらぎ) }\end{array}$ & 72.7 & 78.5 & 62.0 & 87.2 & 76.9 & 75.5 \\
\hline $\begin{array}{l}\text { 綿 } \mathrm{B} \\
\text { (かつらぎ } 6654)\end{array}$ & 62.3 & 62.8 & 68.3 & 82.0 & 69.2 & 68.9 \\
\hline $\begin{array}{l}\text { 綿 C } \\
\text { (かつらぎ) }\end{array}$ & 53.6 & 52.0 & 52.9 & 72.7 & 60.9 & 58.4 \\
\hline $\begin{array}{l}\text { セルメック }{ }^{\circledR} \text { 防塵作業着 } \\
\text { (ポリエステル) }\end{array}$ & 38.7 & 56.9 & 31.1 & 23.7 & 26.2 & 35.3 \\
\hline $\begin{array}{l}\text { メッキンガウン } \\
\text { (不織布：パルプ+ポリエステル十ナイロン) }\end{array}$ & 38.5 & 27.6 & 27.2 & 22.6 & 38.1 & 30.8 \\
\hline $\begin{array}{l}\text { ディスポガウン } \\
\text { (不織布：パルプ+レーヨン十ポリプロピレン) }\end{array}$ & 41.2 & 29.1 & 24.9 & 32.9 & 21.5 & 29.9 \\
\hline
\end{tabular}

表12 マスクの細菌捕集効率 $(\%)^{11)}$

\begin{tabular}{|c|c|c|c|c|c|c|}
\hline \multirow{2}{*}{ マスクの 種 類 } & \multicolumn{5}{|c|}{ テスト 回 数 } & \multirow{2}{*}{ 平均 } \\
\hline & 1 & 2 & 3 & 4 & 5 & \\
\hline グラスファイバ マット+ 2 層の不織布 & 87.5 & 90.5 & 91.3 & 88.2 & 85.2 & 88.5 \\
\hline グラスファイバ マット+ 2 層の不織布 & 90.0 & 92.4 & 86.8 & 86.6 & 86.4 & 88.4 \\
\hline 不織布：パルプ+ポリプロピレン & 66.3 & 62.7 & 70.0 & 65.0 & 68.4 & 66.5 \\
\hline 綿布（綿ネル＋2 層のガーゼ） & 43.0 & 57.7 & 45.5 & 53.5 & 56.7 & 51.3 \\
\hline 不織布：ポリエステル & 31.2 & 46.6 & 33.1 & 51.0 & 35.5 & 39.6 \\
\hline (グラスファイバ マット+2 層の不織布)を 2 重にした場合 & 98.1 & 97.4 & 98.9 & & & 98.1 \\
\hline
\end{tabular}

面吸湿も可能であるので, 将来の商品展開に充分期待で きる。

マスクは，不織布のもっとも進出しやすい部門である と考えられるが，米国の不織布製マスクの $100 \%$ 近い進 出振りに比し，日本ではかなり普及はおくれている.そ の原因としてコスト，医師や看護婦の使い慣れ，使用時 の息苦しさ, 細菌透過阻止力等のいずれを選択するかに 大きく左右されると思われる.

各種不織布の細菌捕集効率を表 $11^{11)}$ 亿各種マスクの細 菌捕集効率を表 $12^{11)}$ に示す

各種不織布製品の米国における傾向を表 $13^{13)}$ に示す.

限られた紙面でメディカル用途の不織布と従来使用さ れてきたものとのすべての比較を，論ずることはむずか しい.

今後，不織布はその特性を生かし加工技術を開発すれ ばてれらの分野に有望である。一方, 前述の医療用不織 布試験法も，でく近い将来公に認知されることになると 思われる.

\section{文献}

1) 昭和 42 年 1 月 20 日 薬事, 企業, 製薬, 監視 4 課長決裁 厚生省薬務局薬事課 ガーゼ代用紙綿類の取り扱いについ $\tau$.

2) 昭和 46 年 9 月 23 日 薬事第327号 厚生省薬務局薬事課長通 知 医薬部外品たる皮膚等の清净用綿類の取扱いについて
表13 不織布の市況

（単位：100万ドル）年間伸び率（\%)

\begin{tabular}{|c|c|c|c|c|c|}
\hline 販 & 1963 & 1976 & 1990 & 実績 & 含後の \\
\hline メディカル/サージカル & 18 & 318 & 1,140 & 24.9 & 9.5 \\
\hline 消 費 財 (一 般) & 6 & 568 & 2,760 & 41.6 & 12.0 \\
\hline 工 業 資 材 & 15 & 84 & 260 & 14.2 & 8.4 \\
\hline 合 & 39 & 970 & 4,160 & 28.1 & 11.0 \\
\hline 品 & & & & & \\
\hline 手術室用綿 布 & - & 48 & 171 & 一 & 9.5 \\
\hline " ガウ ン & - & 41 & 209 & - & 12.3 \\
\hline アンダーバッド & 12 & 131 & 414 & 19.9 & 8.6 \\
\hline シーツおよび枕カバー & 2 & 35 & 126 & 27.4 & 9.6 \\
\hline 紙 お む つ & 7 & 511 & 2,445 & 38.5 & 11.8 \\
\hline ウエットワイプ & - & 27 & 180 & - & 14.5 \\
\hline ワイ パ（家庭用） & 一 & 35 & 150 & - & 11.0 \\
\hline ワイパ（工業用） & 15 & 59 & 165 & 11.1 & 7.6 \\
\hline そ $\quad$ 他 & 3 & 83 & 300 & 30.9 & 9.6 \\
\hline 計 & 39 & 970 & 4,160 & 28.1 & 11.0 \\
\hline
\end{tabular}

不織布製使いすて製品の出荷高.

昭和 46 年 4 月 9 日 薬事第 145 号 厚生省薬務局薬事課長 通知 皮虑等の消毒・清净用綿類の取り扱いについて

3）小西康夫, 高分子, 22, 630 (1973).

4) 芦田真; 医器誌, 42, 503 (1972).

5) 医療用不織布研究委員会, 未発表データ

6) 原素行; セントラル ステーリル サプライ 9290, 医学書院 1976 . 
7）辻楠雄, 目黒賢二, 飯田和子, 水町彰吾, 大場豩磨; 医器 誌, 47, 180 (1977).

8) 芦田真, 荒川洋造, 古川千栄子, 山本直美; 医器誌, 46, 35 (1976).
9）日本清浄綿工業会，昭和 51 年 8 月 15 日調査資料

10）細㴊和成, 佐藤健二; 医器誌，47,184（1977）.

11）宮前卓之, 古橋正吉, 上田伊佐雄; 医器誌, 44, 368 (1974).

12） INDAニュースレター，1977年11・12月合併号

\section{緘維産業に携わる研究者・技術者は日本瀻維機械学会の会員に。}

日本繊維機械学会は，繊維産業（繊維製造〜アパレル〜流通）に携わる研究者・技術者の結集体として昭和 23 年 6 月に創立されました。

以後30年間にわたり我国の繊維技術およびその周辺分野の発展向上に絶ゆまざる努力を続けて参りましたが, 特に本会の特徴として

a . 基礎的研究とその応用

b . 現場技術の向上とその理論的究明

c . 大学, 研究所などと現場との緊密な連係

など創立以来産学協同の線を強く打ち出してきました。

今や繊維産業は循環不況と構造不況が重なり，かつて経験したことのない深刻な状況にあります.

この困難な状況を打破するには，より高度な新技術の開発，設備の近代化，規模・方式の適正化などの面で知 識集約化をはかり衣生活をより高度化するほかありません．このときに当たり本会の使命, 役割はいよいよ重要 であるといえましょう。

学会活動の活発化や会員の相互啓発は会員が多数であればあるほど，より高まり深くなります。会員各位にお かれましてもこの会員増加キャンペーンにご協力いただき，お知り合いの方でまだ末入会の方がおられましたら， ぜひご入会をおすすめいただきたく，あるいは事務局までご一報下さいますようお願いいたします.

\section{正会員・学生会員の入会について}

1.入 会 手 続 申込用紙に所定事項を記入し, 会費を添えて申し込んで下さい.

2. 会費 正会員 年額7 200円 学生会員 年額2 000円

3. 会費納入方法 年度 (4月より翌年 3 月まで) の途中で入会の場合は残余月分の会費を納入して下さい.

4. 会 員 資 格 正 会員…繊維ならびに繊維機械に関する学識経験または関心のある個人. 学生会員…在学中のもの.

5.入 会 承 認 所定の入会手続がすみますと, 当学会より「入会承認書」ならびに会誌「絩維機棫学会誌」を お送りします（ただしバックナンバー希望の場合は別に誌代をいただきます）.

6. 会誌について 会誌「織維機械学会誌」は毎月会員に無料でお送りします。本誌は, 繊維工学の各分野の最新 のテーマを適宜とりあげ詳しく解説し, 諸氏の研究に, 業務に, 大いに役立てていただけるも のです.

入会申込書は巻末57ページにあります.ぜひともこ協カを! 